\title{
Karnofsky Performance Status 0
}

National Cancer Institute

\section{Source}

National Cancer Institute. Karnofsky Performance Status O. NCI Thesaurus. Code

C105720.

Dead. 